RESUMO DE TESE

\section{ANÁLISE DA REATIVIDADE CRUZADA ENTRE SOROS DE PACIENTES COM LEISHMANIOSES, DOENÇA DE CHAGAS OU TOXOPLASMOSE COM ANTÍGENOS DE FORMAS SANGUÍNEAS DE PLASMODIUM FALCIPARUM ATRAVÉS DO TESTE DE IMUNOFLUORESCÊNCIA INDIRETA}

A freqüência de reações cruzadas entre antígenos sanguíneos de formas assexuadas do $P$. falciparum e soros de indivíduos com leishmanioses, doença de Chagas ou toxoplasmose foi investigada através do teste de Imunodeficiência Indireta (IFI). Soros normais e de pacientes convalescentes de malária foram também usados, inicialmente, na avaliação do antígeno preparado com diferentes fixadores e pré-lavagens em salina fosfatada (PBS). Entre os fixadores testados - glutaraldeído, paraformaldeído, ácido acético + etanol, metanol e acetona - a acetona forneceu melhores resultados. No entanto, o uso de antígenos fixados com acetona ou não fixados forneceu semelhantes títulos com os soros controlepositivos de pacientes com malária. Soros controlepositivos diluídos em $\mathrm{PBS} /$ tween apresentaram fluorescência mais intensa do que aqueles diluídos com PBS sem tween, facilitando a leitura. No entanto, os títulos foram semelhantes em ambos os casos. Soros humanos diluídos $20 \mathrm{X}$ em PBS/tween apresentaram a seguinte reatividade com antígenos de $P$. falciparum não fixados (secos ao ar): os 23 (100\%) soros de indivíduos com malária foram positivos; 7 (87\%) dos 8 soros de leishmaniose visceral foram positivos; $33 / 50(66 \%)$ soros de leishmaniose tegumentar foram positivos; $21 / 44$ (48\%) soros de doença de Chagas foram positivos; $8 / 30$ soros $(27 \%)$ de toxoplasmose foram positivos e 4/20 (20\%) soros normais foram positivos. Curiosamente, na toxoplasmose, doença causada por um parasita do mesmo filo Apicomplexa, no qual estão os parasitas da malária, ocorreu o menor índice de reatividade cruzada, semelhante aos soros normais. Não houve correlação entre os títulos dos soros para o antígeno específico nessa protozooses

\section{ANALYSIS OF THE CROSS REACTIVITY BETWEEN SERA FROM PATIENTS WITH LEISMANIASIS, CHAGAS' DISEASE OR TOXOPLASMOSIS TO ANTIGENS OF PLASMODIUM FALCIPARUM ASEXUAL BLOOD STAGES BY INDIRECT IMMUNOFLUORESCENCE}

The frequency of cross reaction between antigens of $P$. falciparum asexual blood stages and sera from individuals with leishmaniasis, Chagas' disease or toxoplasmosis was studied by indirect immunofluorescence (IIF). Sera from malaria convalescent patients and from normal individual were also used, initially, to evaluate the antibody reactivity to antigens prepared with diferent fixatives and washes prior to the reaction with phosphate buffer saline (PBS). Among the fixatives used glutaraldehyde, paraformaldehyde, acetic acid+ethanol, methanol and acetone - the latter gave the best results. However, acetone-fixed or air-dried antigens gave similar results with the positive control human malaria sera. The positive control sera diluted in PBS/tween although had stronger IIF, thus facilitating the reading, showed similar titers of positive reactions to those diluted in PBS without tween. Sera diluted 20x in PBS/tween gave the following reactivity to $P$. falciparum nonfixed (air-dried) antigens: all $23(100 \%)$ sera from individuals with malaria were positive; 7 (87\%) out of 8 sera with visceral leishmaniasis were positive; $33 / 50(66 \%)$ sera with cutaneous leishmaniasis were positive; $21 / 44$ (48\%) sera with Chagas' disease were positive; $8 / 30(27 \%)$ sera with toxoplasmosis were positive and 4/20 (20\%) normal sera were positive. Surprisingly, individuals with toxoplasmosis, a disease caused by a parasite of the same phylum Apicomplexa, in which the malaria parasites are enclosed, showed the lowest cross reactivity indices, similar to normal sera. We did not find any correlation between antibody titers

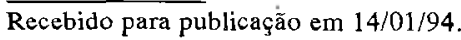


Resumo de Tese. Abramo C. Análise da reatividade cruzada entre soros de pacientes com leishmanioses, doença de Chagas ou toxoplasmose com antigenos de formas sanguineas de Plasmodium falciparum através do teste de imunofluorescência indireta. Revista da Sociedade Brasileira de Medicina Tropical 27:107-108, abr-jun, 1994.

e os títulos para o antígeno do $P$. falciparum, ou seja, altos títulos para o antígeno específico não implicaram em reatividade cruzada com o antígeno de $P$. falciparum. Considerando o título de 20 ou 80 como limite de positividade, a sensibilidade do teste de IFI foi de $100 \%$ e $96 \%$, respectivamente, e sua especificidade foi de $52 \%$ e $90 \%$, respectivamente. Portanto, a escolha da diluição final dos soros a șer considerada positiva para malária deve ser feita conforme os parasitas prevalentes na população. with the specific antigen in each disease and those with $P$. falciparum antigens, i.e. high specific titers did not imply in high anti-P. falciparum titers. Considering the sera titers os 20 or 80 as the positive limit, the sensitivity was $100 \%$ and $96 \%$, respectively, and the specificity was $52 \%$ and $90 \%$, respectively. Therefore, the choice of the final positive dilution of sera may be done according to the parasites prevalent in the population.

Clarice Abramo

Tese apresentada ao Centro de Pesquisas René Rachou, Fundação Oswaldo Cruz, para obtenção do Título de Mestre.

Belo Horizonte, MG, Brasil, 1993. 